Maria, T., Transition to online learning by a teacher education program with limited 4IR affordances

\title{
Transition to online learning by a teacher education program with limited 4IR affordances
}

\author{
Maria Tsakeni \\ University of the Free State, School of Mathematics, South Africa \\ E-mail: tsakenim@ufs.ac.za \\ Received : 2021-06-18 \\ Revised : 2021-07-29 \\ Accepted : 2021-08-21 \\ $10.46303 /$ ressat.2021.15
}

\begin{abstract}
How to cite this paper: Maria, T. (2021). Transition to online learning by a teacher education program with limited 4IR affordances. Research in Social Sciences and Technology, 6(2), 129-147. https://doi.org/10.46303/ressat.2021.15

This is an Open Access article distributed under the terms of the Creative Commons Attribution 4.0 International license (https://creativecommons.org/licenses/by/4.0/).
\end{abstract}

\section{Abstract}

This study used the community of inquiry (Col) framework and the affordances of Internet of things (IOT) to explore how the faculty of education of a rural campus of a university transitioned from face-to-face to online modes of instruction. In this qualitative interpretive study, data were collected through open-ended questionnaires from four purposely selected teacher educators and five final-year bachelor of education preservice teachers. Thematic content analysis techniques were used to analyze the data collected. The findings indicated the tensions experienced by the teacher educators as they negotiated the limited loT affordances to ensure effective teaching, cognitive, and social presence in the newly formed online classrooms. Some of the tensions included the choices that were made on whether to use synchronous or asynchronous modes of instruction and the selection of effective communication modes. The teacher educators used a combination of the official learning management system (LMS) tools of the university and a social media platform as way of navigating the limited 4IR environments experienced by the preservice teachers.

Key words: community of inquiry; COVID-19; Internet of things; online learning; teacher education

\section{Introduction}

Although the transformation of learning in educational institutions was inevitable due to the increased pervasiveness of technologies inherent to the Fourth Industrial Revolution (4IR) (DeNoyelles et al., 2014; McGinnis, 2018; Schwab, 2016), the advent of the COVID-19 pandemic forced the institutions to abruptly embrace the change. Carrillo and Flores (2020) confirmed that educators were forced to shift from face-to-face to remote learning, while Panergayo and Almanza (2020) described the change as a shift from conventional to flexible learning. COVID19 came at a time when literature such as Saadatmand et al. (2017) had been observing a 
Maria, T., Transition to online learning by a teacher education program with limited 4IR affordances

growing trend in the use of online learning in higher education institutions. On the onset of the pandemic and the subsequent mitigation lockdown measures, one of the significant changes made by institutions of higher learning was to move from face-to-face to online modes of instruction. This move seemed to be the reasonable option given that $90 \%$ of the student population was out of school (Commonwealth of Learning, 2020). The compelled shift from face-to-face to online instructional modes in institutions of higher education came at a time when there was a notable breakthrough in the development of online learning.

The notable development in online learning was based on the use of learning management systems (LMSs) by institutions of higher education (Mershad \& Wakim, 2018). Aldowah et al. (2017) confirmed that there has been a marked increase in the use of LMSs such as Blackboard and Moodle to facilitate online learning. In addition to the potential of LMSs to transform online learning is the use of social media and online tools that provide learners with expanded opportunities to interact, share content, and connect (Saadatmand et al. 2017). As Scott et al. (2016) explained, the use of Web 2.0 tools, which include social media and web-based office tools, expands the teaching and learning opportunities because learners can create, edit, and share content and communicate and view content posted by instructors and other learners. The growth of online learning is made possible by the Internet of things (IoT), one of the 4IR technologies.

The loT is a technology that enables the interaction between real and virtual objects, creating an ecosystem capable of supporting numerous applications, including online learning (Abbasy \& Quesada, 2017). As Hernandez et al. (2018) elaborated; the loT is an intersection of people, processes, data, and things, creating connections with more capabilities and enhanced experiences. Swarts (2020) reiterated that technologies have enabled educational interaction and connection at local and global levels. The sudden shift from face-to-face to online learning due to the COVID-19 pandemic opened opportunities and the need to study the affordances of the loT infrastructure supporting online learning and to explore ways of improving instructional strategies. Shea and Bidjerano (2012) suggested that studying through online learning should be framed by appropriate models that assist in determining how to improve instructional strategies. The community of inquiry (Col) framework by Garrison et al. (2000) is one of the most widely used frameworks to study online learning.

The Col framework portrays online learning as a collaborative process defined by three components: teaching presence, cognitive presence, and social presence (Thompson et al., 2017). Some of the factors influencing online learning stem from how the three forms of presence are facilitated (Szeto, 2015). In addition, the affordances of the loT also influence online learning and one of the highlighted issues is that of equitable access by the students (Cutri et al., 2020). Catalano et al. (2021) observed that students in high-needs schools struggled to complete assignments in online classrooms created due to the COVID-19 pandemic. This study explored how one teacher education program transitioned to online learning as prompted by the advent of the COVID-19 pandemic at a rural campus of a South African university. The study sought to address the question: How did a teacher education program in rural South Africa transition to online learning during the COVID-19 pandemic? The study contributes insights on the experiences of online learning during the COVID-19 pandemic by teacher education programs. 
Maria, T., Transition to online learning by a teacher education program with limited 4IR affordances

\section{Research Questions}

The main research question for this study is: How did a teacher education program in rural South Africa transition to online learning during the COVID-19 pandemic? The main question was addressed using the following subsidiary questions:

1. What loT technology affordances were used by the rural education program to support online learning?

2. How was teaching presence ensured by the rural teacher education program in online classrooms?

3. How was social presence ensured by the rural teacher education program in online classrooms?

4. How was cognitive presence ensured by the rural teacher education program in online classrooms?

\section{Review of Literature}

The transition to online learning in this study is viewed as the rapid move to build and use online classrooms in place of the traditional face-to-face classrooms as prompted by the COVID-19 pandemic. Cutri et al. (2020) point out that the transition to online classrooms was done with little or no preparation by the instructors and the learners. Cutri et al. (2020) also point out that the transition was conducted under traumatic conditions since there was no indication of how long it would be necessary to continue with online learning. As a result, teachers and teacher educators experienced intensified workloads caused by uncertainties that characterized the sudden shift to online classrooms (Allen et al., 2020; Subedi \& Subedi, 2020). A study conducted in Nepal by Lemay et al. (2021) showed that during the transition to online learning, the instructors lacked experience and received little guidance. The instructors also worked with few resources which was compounded by the economic hardships and threats to their health. Due to the challenges experienced by both the learners and the instructors in online classrooms during the COVID-19 pandemic, Baran and AIZoubi (2020) proposed a human-centred approach to facilitate the transition to online learning. The approach is based on three pillars: the building of empathy, pedagogical problem-solving, and the establishment of online communities of inquiry.

The building of empathy is important because as Williams et al. (2021) observed, there are inequitable access to technology and limited digital efficacy issues experienced by learners in online classrooms. One of the challenges for teacher education is to determine ways in which the preservice teachers can fulfil the work-integrated learning requirements of the teachers' qualification when face-to-face learning is not possible (Mutton, 2020; Isidro \& Teichert, 2021). Carrillo and Flores (2020) concluded that teacher education needs to adapt by developing new pedagogies in the wake of online learning.

Online learning is supported by the pervasiveness of the fourth industrial revolution (4IR) environments in the society. The $4 I R$ according to Melville and Robert $(2021, p .1)$ refers to the "productivity-enhancing industrial innovations enabled by rapid technological progress and combinations of digital technologies." Online learning relies on the 4IR environments and tools which unfortunately are limited for learners from poor communities. In order to explore 
Maria, T., Transition to online learning by a teacher education program with limited 4IR affordances

transition to online learning this study used the Col framework as lens to explore online learning and the IoT as a lens to explore the limitations of the 4IR.

\section{Community of Inquiry and Online Learning}

Research on online learning started well before the start of the COVID-19 pandemic. Nonetheless, before the pandemic, there was a notable underutilization of technological tools to facilitate online learning (Arroio, 2020). One of the models widely used to study and inform online learning is Col attributed to the work of Garrison et al. (2000). DeNoyelles et al. (2014) pointed out that the Col framework was initially developed to serve as a framework for asynchronous text-based discussions but was later adapted to study online learning.

The Col framework is defined by three crucial components that underpin online learning experiences, which are teaching presence, cognitive presence, and social presence. Teaching presence is defined by Anderson et al. (2001) as what instructors do to design, facilitate, and direct the other two forms of presence (cognitive and social) in order to achieve educational objectives. The teaching presence is further broken down into three components, which are instructional organization, facilitating discourse, and direct instruction. DeNoyelles et al. (2014) explained that instructional organization entails the structure, process, facilitation, and evaluation of online learning interactions. In facilitating the discourse, the discussions aim to explain the main ideas, seeking clarity, and misconceptions are identified. Lastly, through direct instruction, the instructor, tutor, or any participant in the discussion who is more knowledgeable in the subject articulates what is important to learn.

Cognitive presence refers to the experiences of meaning-making through the interactions in the online classroom. Thompson et al. (2017) posited that cognitive presence experiences are where the hard work of knowledge construction happens. Cognitive presence is sustained and made possible through four progressive phases, starting with a triggering event, followed by exploration, integration, and, finally, resolution (DeNoyelles et al., 2014). Face-to-face learning by default presents a social setting in which the instructor and the learners are physically present engaging in activities to achieve the educational goals. Online classrooms lack dynamic face-to-face interactions (Shea \& Bidjerano, 2012), although social presence can nonetheless be built.

Social presence is viewed from the sense that the individuals engaged in online learning are part of a group (Thompson et al., 2017). Through social presence, learners project themselves as real people in environments mediated by online tools by interacting and communicating (DeNoyelles et al., 2014).

From the literature reviewed, it is noted that learners need to demonstrate a certain degree of active participation for learners to be successful in online learning. Shea and Bidjerano (2012) propounded that learner self-regulation, which they call learner presence, is an important requirement for online learning. Consequently, Chang et al. (2019a) observed that learners who are active in discussion forums are more likely to be successful in online learning. Similarly, Chang et al. (2019b) posited that for learners to be successful in large online courses, they need to possess qualities that help them to learn with little assistance from the instructors. These qualities are encapsulated in self-regulated learning, which Cho et al. (2017) explained is the process in which learners manage their own learning to achieve set goals using motivational 
Maria, T., Transition to online learning by a teacher education program with limited 4IR affordances

qualities that include personal goal setting, self-confidence, beliefs in ability to learn, and high task value. However, Szeto (2015) highlighted the importance of teaching presence for the success of online learning because of the leadership role it plays, but the author quickly pointed out that the experiences of the three components of presence are context specific. Hajibayova (2017) confirmed the leadership role of the teaching presence upon concluding that learners appreciate the flexibility of online learning, instructor timely feedback, and frequent engagement through various media. Multimedia is also used to enhance social presence in online learning (Borup et al., 2012; Krutka et al., 2017; Lowenthal, 2010). The multimedia used include social media, videos, and digital storytelling. However, Krutka et al. (2017) observed that the use of social media pedagogies may result in shortcomings in course structure and facilitation due to mismatches between instructor and learner expectations.

\section{Internet of Things and Online Learning}

The loT is an emerging technology that is increasingly having an impact on our everyday lives, including education (Kortuem et al., 2013). As such, there have been several attempts to provide a definition of the technology in literature. This includes that the IoT is a connection of virtual and physical objects that are able to communicate with each other through sensing and other interactions (Abbasy \& Quesada, 2017; Hernandez et al., 2018). One of the areas impacted by the loT technology is higher education, including teacher education. In education, the loT supports the interaction of physical and virtual objects embedded with instructional technologies, mobility applications, and cloud computing (Aldowah et al., 2017; Kalimullina et al., 2021). The instructional technologies include LMSs such as Blackboard, Sakai, and Moodle. IoT technologies also enable the integration of mobile learning applications used by learners to manage learning and used by instructors to administer assessments and teach through simulations. An example of where teaching through simulations was achieved was the development of a module with smart features that consisted of a smart backpack, loT school check-in, smart desk, and whiteboard (Bayani et al., 2017). The smart module provides a virtual and flexible learning environment supported by the loT.

The loT is noted for enriching opportunities and experiences in education. Abbasy and Quesada (2017) used the concept of IoT to explain a model in education coined as Internet of education things (IOET). The loET model comprises several affordances, including the promotion of engaged learning by improving the learners' degree of attention, motivation, interest, and curiosity. The IoET environments allow learners to engage in creativity as they use skills to observe the world in new and diverse ways when interacting with virtual and physical objects. E-learning is possible through the loET through the use of electronic tools, applications, and web-based tools. Among the affordances enabled by the loET is the capability of self-learning in which learners are motivated to self-educate in informal and flexible environments.

Furthermore, remote collaborations are enabled among people in different locations. LMSs and Web 2.0 tools such as social media and web-based office tools such as Google and Microsoft are some of the loT-enabled technologies used to build online learning ecosystems (Scott et al., 2016). Makamure and Tsakeni (2020) observed that the WhatsApp social media platform played a significant role in building online classrooms during the COVID-19 pandemic. The advent of online learning has also influenced teacher education. For teacher education, the 
Maria, T., Transition to online learning by a teacher education program with limited 4IR affordances

implications of online learning are far-reaching because the students use online learning for their education and are also being prepared for online classroom practice.

\section{Methods}

\section{Research design}

The research design comprised a qualitative study guided by an interpretive paradigm using rural campus of one South African university as a research site. The interpretive paradigm allowed for the understanding of the findings of the study as subjective experiences of the study participants (Kivunja \& Kuyini, 2017). Qualitative research gave voice to the participants and the researcher only made meaning of how they (the participants) viewed the phenomenon under study (Creswell, 2014). The phenomenon under study entailed the subjective experiences of a transition to online learning by a faculty of education.

\section{Context}

The university has two other campuses in urban settings. Literature regards rural contexts as non-urban areas that have fewer civic and commercial amenities and are characterized by social justice issues, which includes poor service delivery (Manly et al., 2020; Nelson et al., 2021). The poor service delivery includes poor access to electricity and the internet. This study was conducted in a context in which a significant number of the students enrolled at the campus lived in rural communities of the Eastern Free State and KwaZulu-Natal provinces of South Africa. However, the university campus is not affected in the same way as the rural community by the intermittent electricity supply and internet access because it has a backup electricity generator and reliable internet infrastructure. However, the transition to online learning happened at the time both the students and educators were studying and working from home, respectively, due to the COVID-19 pandemic.

\section{The participants}

The participants consisted of 4 teacher educators who taught education courses attended by all fourth-year BEd students. Two of the teacher educators taught a general education course, while the other two taught the teaching practice course, as shown in Table 1.

Table 1. Teacher-educator Participants

\begin{tabular}{|l|l|l|l|}
\hline $\begin{array}{l}\text { Teacher- } \\
\text { educator } \\
\text { participant }\end{array}$ & Course taught & Gender & Home environment \\
\hline T1 & General education & Male & Rural community \\
\hline T2 & General education & Male & Rural community \\
\hline T3 & Teaching practice & Male & Rural community \\
\hline T4 & Teaching practice & Female & Rural community \\
\hline
\end{tabular}

Five fourth-year preservice teachers from a BEd program also formed part of the participants that was purposely selected from different specializations, as shown in Table 2. 
Maria, T., Transition to online learning by a teacher education program with limited 4IR affordances

Table 2. Preservice-teacher Participants

\begin{tabular}{|l|l|l|l|}
\hline $\begin{array}{l}\text { Preservice- } \\
\text { teacher } \\
\text { participant }\end{array}$ & BEd specialization & Gender & Home environment \\
\hline PST1 & $\begin{array}{l}\text { Primary school social } \\
\text { sciences }\end{array}$ & Female & Rural community \\
\hline PST2 & $\begin{array}{l}\text { Primary school science } \\
\text { and mathematics }\end{array}$ & Female & Rural community \\
\hline PST3 & $\begin{array}{l}\text { Secondary school } \\
\text { science and mathematics }\end{array}$ & Male & Rural community \\
\hline PST4 & $\begin{array}{l}\text { Secondary school history } \\
\text { and languages }\end{array}$ & Male & Rural community \\
\hline PST5 & $\begin{array}{l}\text { Secondary school } \\
\text { business studies and } \\
\text { economics }\end{array}$ & Male & Rural community \\
\hline
\end{tabular}

An invitation was sent to all teacher educators who had participated in the transition to online learning and taught all the preservice teachers in the BEd program. Purposive sampling was further used to select teacher educators who lived in the rural communities around the university campus. Purposive sampling was also used to select five final-year preservice teachers from different BEd specializations but attended the mass courses teaching practice and general education taught by the teacher-educator participants. The selected preservice teachers lived in rural communities during the time that the online learning was implemented. The pseudonyms T1-T4 were assigned to the teacher educators, while the preservice teachers were assigned the codes PST1-PST5. T1-T3 were male teacher educators and T4 was a female teacher educator. PST1 and PST2 were female preservice teachers and PST3-PST5 were male preservice teachers.

\section{Data Collection Instruments}

Two open-ended questionnaires, one for the teacher educators and another for the preservice teachers, were designed to elicit insights of the transition to online learning. The first section of the teacher educators' questionnaire elicited biographical data in terms of gender, course taught, and place lived during the online learning. Similarly, the first part of the preservice teachers' questionnaire elicited information on gender, BEd specialization and place lived during online learning. The second part of the questionnaire elicited the loT tools that supported the online learning as experienced by the teacher educators and the preservice teachers respectively. The third part of the teacher educators' questionnaire elicited how they facilitated the three components of Col, teaching presence, social presence, and cognitive presence, in online learning and the loT tools that were used. The third part of the preservice teachers' questionnaire probed the experiences they had of teaching presence, social presence, 
Maria, T., Transition to online learning by a teacher education program with limited 4IR affordances

cognitive presence, and the loT tools used. Therefore, the questions on the questionnaires were under the three headings: biographical data, loT tools used, and the Col experiences.

\section{Data collection procedures}

The study was conducted in November 2020. An email with the open-ended questionnaire were sent to the fifteen teacher educators who had participated in the transition to online learning in the faculty of education. Ten completed questionnaires were returned. However, four were selected purposefully according the participant selection criteria explained under the description of the participants. Similarly, an email with the questionnaire was sent through the Blackboard LMS of the teaching practice course and general methods course to the fourth-year BEd preservice teachers. Five questionnaires were selected according to the criteria explained in the section describing the participants. The questionnaires were labelled T1-T4 and PST1PST5 accordingly.

\section{Trustworthiness}

The trustworthiness of the data, which is a measure of credibility and authenticity, was ensured through theory triangulation. The data collection and analysis were based on the Col and IoT frameworks. Participant triangulation was also used because the questionnaire was applied to the teacher educators and the preservice teachers to elicit the two sides of the story of how transition to online learning occurred.

\section{Data Analysis}

The textual data collected from the open-ended questionnaires were subjected to thematic content analysis following the steps suggested by Nowell et al. (2017). The steps entailed reading completed questionnaires repeatedly in order to be familiar with the data. The read texts were subjected to a coding process. The researcher developed codes to identify the subsidiary research question, participant and the theme into which the data must be classified. For example, as shown in Table 3 pieces of data may be labelled as SQ1-T1-IOT-1 or SQ1-T1IoT-2 to show that the pieces of data address the subsidiary research question 1 and have been extracted from T1's completed questionnaire and that the data falls under the loT broad theme but they are different and therefore are labelled 1 or 2 at the end of the code. The following labels were used to build the codes, SQ-subsidiary question, IoT-Internet of Things, TP-teaching presence, SP-social presence, $\mathrm{CP}$-cognitive presence, and the T1-T4 for teacher educators and PST1-PST5 for the preservice teachers. Table 3 only shows a few examples and not all the data that were analyzed. The coded data was placed into categories that were further grouped in the predetermined themes that addressed the four subsidiary questions. 
Table 3. Excerpt from the Open-ended Responses Codebook

\begin{tabular}{|c|c|c|}
\hline Broad theme & Instructor-learner activities & Categories \\
\hline IoT affordances & $\begin{array}{l}\text { LMS tools } \\
\text { Social media tools } \\
\text { Online office tools } \\
\text { Other multimedia }\end{array}$ & $\begin{array}{l}\text { Connectivity } \\
\text { challenges } \\
\text { Use of Blackboard } \\
\text { Use of WhatsApp }\end{array}$ \\
\hline Example & $\begin{array}{l}\text { I used online learning, which included } \\
\text { Blackboard and WhatsApp. These assisted me } \\
\text { to reach many students, especially those from } \\
\text { remote areas without adequate access to } \\
\text { resources and internet connectivity. SQ1-T2- } \\
\text { loT-1 }\end{array}$ & $\begin{array}{l}\text { Use of LMS and social } \\
\text { media }\end{array}$ \\
\hline Teaching practice & $\begin{array}{l}\text { Instructional organization } \\
\text { Facilitating discourse } \\
\text { Direct instruction }\end{array}$ & $\begin{array}{l}\text { Asynchronous online } \\
\text { instructional } \\
\text { strategies }\end{array}$ \\
\hline Example & $\begin{array}{l}\text { I staggered my presentations and assignments } \\
\text { in such a way they will keep my students busy } \\
\text { when doing entire unit. My students will be } \\
\text { studying and doing various parts of the } \\
\text { assignments alongside my PowerPoint } \\
\text { presentation with a voiceover. On weekly basis, } \\
\text { I also sent reminders and allowed students to } \\
\text { submit for me to give comments. SQ2-T1-TP-1 }\end{array}$ & $\begin{array}{l}\text { The leadership role of } \\
\text { teaching presence }\end{array}$ \\
\hline Social presence & $\begin{array}{l}\text { Discussions } \\
\text { Interactions } \\
\text { Communications } \\
\end{array}$ & \\
\hline Example & $\begin{array}{l}\text { I allowed students to form groups in some } \\
\text { activities and submit their work as groups. In } \\
\text { addition, in one module I also allowed them to } \\
\text { give one another a mark that would contribute } \\
\text { about } 5 \% \text { of the promotion mark. This was an } \\
\text { acknowledgement/penalty of the } \\
\text { [non-]contribution of each member of the } \\
\text { group from the perspective of members of the } \\
\text { same group. SQ3-T1-SP-1 }\end{array}$ & $\begin{array}{l}\text { Learner-learner } \\
\text { interactions through } \\
\text { groupwork and peer } \\
\text { evaluation }\end{array}$ \\
\hline $\begin{array}{l}\text { Cognitive } \\
\text { presence }\end{array}$ & $\begin{array}{l}\text { Triggering event } \\
\text { Exploration } \\
\text { Integration } \\
\text { Resolution }\end{array}$ & \\
\hline Example & $\begin{array}{l}\text { Recorded lesson and video lesson don't form } \\
\text { that active teaching and learning so much; one }\end{array}$ & $\begin{array}{l}\text { Self-regulated } \\
\text { learning }\end{array}$ \\
\hline
\end{tabular}


Maria, T., Transition to online learning by a teacher education program with limited 4IR affordances

\begin{tabular}{|l|l|l|}
\hline & $\begin{array}{l}\text { will listen to the lesson at his or her own time, } \\
\text { which is one of the advantage to some. SQ4- } \\
\text { PST1-CP-1 }\end{array}$ & \\
\hline
\end{tabular}

\section{Findings of the Study}

The findings of the study address the following main question: How did a teacher education program in rural South Africa transition to online learning during the COVID-19 pandemic? The findings are presented under four themes that correspond to the four subsidiary questions of the study. The four themes are: loT technology affordances to support online learning, strategies to ensure teaching presence, strategies to ensure social presence, and strategies to ensure cognitive presence. The verbatim data excerpts used in this section were selected on the basis that they represented the views of all the participants.

\section{Internet of Things Technology Affordances to Support Online Learning}

Discussion of this theme provides insights into the technologies used to support online learning, the issues of access to technologies, and the instructional strategies used to teach in online classrooms. The Blackboard LMS and the WhatsApp social media platform were identified as the loT-enabled technologies used to support online learning. T2 explained how he used a combination of the LMS and the social media platform. He said:

I used online learning, which included Blackboard and WhatsApp. These assisted me to reach many students, especially those from remote areas without adequate access to resources and internet connectivity.

The use of the WhatsApp social media platform was confirmed by PST5 when he said:

This method of interaction and communication was very effective compared to emails as lecturers responded quickly and were able to attend [to] every student's problems. It also enabled lecturers to do voice notes, send extra study materials and images to clarify other information. Lecturers also used this social media platform to remind students about assessment tasks and due dates. It can be used ...easily and does not require lot of training.

The LMS was the official university platform for the facilitation of online learning, but the teacher educators and the preservice teachers made decisions to include the use of the social media platform. One of the issues raised by PST3 was that some preservice teachers did not have computers, laptops, and other gadgets that would enable them to engage in online learning effectively. He also mentioned that the limited access to data was a hindrance to the use of loT-enabled online learning applications. He said:

There was a lack of access to technological devices and data. There was discrimination and an assumption that all students who are not funded by the National Student Financial Aid Scheme (a government-funded scheme to provide loans to university students) can afford to purchase their own laptops and data.

PST4 mentioned the issue of poor internet connectivity experienced in the rural communities as one of the factors that hindered online learning. He said: 
Maria, T., Transition to online learning by a teacher education program with limited 4IR affordances

The unavailability of network (internet connectivity) due to geographical barriers. In locations (rural communities), there is a huge gap of strong connectivity and no connectivity in some areas situated near mountains, whereas our peers in towns suffer less from connectivity problems.

The challenges mentioned above are some of the factors that led to the use of both synchronous and asynchronous modes of online learning. Distance learning through the sending of printed materials to preservice teachers who had limited access to the internet was also used as a strategy of making sure no student was left behind. T1 said the following when explaining the strategies that he used:

The printed material for the rural campus students, PowerPoint presentation with a voice, Blackboard Collaborate, as well as the low-tech (low technology) TEACHON (university online learning support for instructors) and LEARNON (university online support for students) platforms. Other platforms included WhatsApp groups.

Among the online strategies were the use of recorded lectures such as PowerPoint presentations with voiceovers posted on the LMS or the WhatsApp platform. In summary, the rural campus used the university LMS and a social media platform to facilitate online learning. The limited access to the internet due to the lack of data, suitable devices, and poor connectivity by the preservice teachers led to the use of synchronous and asynchronous online learning strategies. Printed material was also sent to some preservice teachers who needed them as one of the distance learning strategies in addition to online learning.

\section{Strategies to Ensure Teaching Presence}

Although there was a possibility of using synchronous online classrooms through the LMS application, there was more evidence that the teaching presence was ensured through the use of asynchronous strategies. The asynchronous strategies included posting content on the LMS for the students to download. T3 said:

I posted lecture slides (PowerPoint presentations) and content on Blackboard. I would have loved to use Blackboard Collaborate (synchronous online learning classroom), but with the large classes it is almost impossible.

T4 explained that she made sure to use the LMS at least once a week (possibly posting content) and also used emails to explain points that needed to be clarified. She said:

I contact my students via Blackboard weekly and make sure that I reply to their emails whenever they need some clarity.

Similarly, T2 ensured teaching presence by posting audio recordings of the content that he needed to teach. He said: "I ensured teaching presence through the use of slides with notes and voiceovers, and WhatsApp voice notes."

In addition to the voice recordings and posting of content, $\mathrm{T} 1$ sent constant reminders to the preservice teachers to ensure they stayed focused on their tasks, and provided feedback on the submissions made. He said: 
Maria, T., Transition to online learning by a teacher education program with limited 4IR affordances

I staggered my presentations and assignments in such a way that will keep my students busy when doing the entire unit. My students will be studying and doing various parts of the assignments alongside my PowerPoint presentations with a voiceover. On weekly basis, I also sent reminders and allowed students to submit their work for me to give comments.

PST2 confirmed that clarifications and explanations of concepts were sent through emails to preservice teachers. She said: "The use of emails was effective as the lecturers gave feedback to each student that made enquiries."

PST4 confirmed that the teacher educators used presentations with voiceovers and video attachments that showed demonstrations of practical work activities. He said:

A PowerPoint-presentation slide with a voice recorded on each slide providing explanations. A PowerPoint presentation with a video attached for demonstration of practical work.

The teaching was ensured by frequent (weekly) posting of content, which included presentations with voiceovers, voice notes through WhatsApp, and texts containing explanations and clarifications sent through emails.

\section{Strategies to Ensure Social Presence}

The synchronous online classrooms were considered to present opportunities of enhanced social presence because the preservice teachers could interact with the teacher educators and among themselves. PST1 considered that the synchronous online lessons enabled the preservice teachers to engage with the teacher educators more and that the use of discussion forums and chat boxes enabled the preservice teachers to engage with one another. She said:

The effective online learning used was through live sessions because one had a chance to engage with others and the lecturer. During the online session, there was a chat box to communicate with classmates; in this way, we were also learning from each other. Discussion forums are also effective because one shares information and it gives one an opportunity of being a creative thinker and be able to help others with problem-solving. This also develops one's communication skills.

T1 encouraged the preservice teachers to interact with peers and participate in the online classrooms through the use of groupwork and peer evaluation. He said:

I allowed students to form groups in some activities and submit their work as groups. In addition, in one module I also allowed them to give one another a mark (evaluate each other) that would contribute about $5 \%$ of the promotion mark. This was an acknowledgement of the group members' contribution and penalty for not contributing from the perspective of members of the same group.

Similarly, T3 gave the preservice teachers groupwork activities and made use of discussion forums. He said:

I asked them to do assignments in groups so that they get to discuss the content amongst themselves. I opened discussion groups on Blackboard as well. 
Maria, T., Transition to online learning by a teacher education program with limited 4IR affordances

Groupwork activities, discussion forums, peer evaluation, and interactions in synchronous online classrooms were used where possible to build the social presence in online learning.

\section{Strategies to Ensure Cognitive Presence}

PST3 considered the discussion forums to be useful for the construction of meaning through collaboration. He described a situation where the preservice teachers would be required to have a minimum of five posts in the discussion forums. He said:

Blackboard Collaborate discussion rooms were the most effective for student-interaction. Here, the lecturer set up four discussion rooms with different topics, then students had to pick one topic and compile a discussion. Other students would respond in agreement or disagreement with justifications. There was a submission date for each response and students were expected to respond to a minimum of five posts; we were then graded on each response. This was the most effective and enjoyable tool for me and it should be used for group assignments in the future, as meeting up physically with groups is always a hassle.

PST1 agreed with the notion that discussion forums helped the preservice teachers in knowledge construction when she explained that although recorded lessons can be listened to at one's convenience, they are passive ways of learning. She said:

Recorded lessons and video lessons are not forms of active teaching and learning. However, one will listen to the lesson at his or her own time, which is one of the advantages to some people.

In this section, the evidence showed that the preservice teachers could learn actively through collaboration and knowledge co-construction in online social interactions or they could learn passively by listening to recorded lessons and videos.

\section{Discussion}

In this section, the discussion will begin by a summary of the findings in order to address the main question. The summary will be followed by a discussion focused on each of the subsidiary questions. This study set out to explore how a teacher education program at a rural campus of a South African university transitioned to online learning during the COVID-19 pandemic. As a contextual assumption, rural communities suffer social justice issues because they are marginalized in terms of limited access to civic and commercial amenities, and suffer poor service delivery, including limited access to education (Manly et al., 2020; Nelson et al., 2021). The study contributes insights on the online learning experiences in the context of the COVID19 pandemic and the experiences of online learning in rural contexts

The findings of the study showed that there were limited loT affordances that influenced how the online classrooms were built and the choice of the online tools used. The limited IOT affordances were mainly due to the unreliable internet connection. Williams et al. (2021) confirm that the different communities in society do not equitably access digital technologies. 
Maria, T., Transition to online learning by a teacher education program with limited 4IR affordances

The university LMS had to be complemented by a social media platform that was easily available and cheap in the transition to online learning. Social media platforms play a significant role in building online classrooms (Saadatmand et al. 2017; Makamure \& Tsakeni, 2020). Therefore, the teaching presence was established mainly through recorded material posted on the LMS and the social media platform for the preservice to download at a convenient time when they connected their devices to the internet from both the LMS and WhatsApp.

In the absence of synchronous online classrooms, the due dates for assessment submission were one way to pace the teaching and learning and help the preservice teachers focus on their tasks. The social presence interactions were mainly between the teacher educator and individual preservice through emails and text messages through WhatsApp. Discussion forums through the LMS were also used, but as mentioned, the students could only participate when they were connected to the internet. The cognitive presence was defined by passive learning in which the preservice teachers interacted with the posted material most of the time to construct meaning. The reduced social interactions limited opportunities for the active coconstruction of meaning.

The four findings according to the four subsidiary questions will be discussed next. The first finding was that contextual factors influenced the loT affordances that supported online learning in the rural communities in which the study participants lived. The contextual factors included limited internet connectivity and preservice teachers who lacked appropriate devices and data to engage in online learning successfully. Cutri et al. (2020) confirmed that inequitable-access issues characterize online learning. Limited access to the internet led to the use of a mix of the university's official LMS (formal learning platform), emails, and a social media application (informal platform) to facilitate online learning. The informal platforms built by the use Web 2.0 tools expand the opportunities for online learning because they enable the sharing of content and facilitate easy and temporal communication (Scott et al. 2016). Synchronous online instructional strategies through the LMS were not always possible due to the poor internet connectivity and were complemented by the use of asynchronous "low-technology" approaches and social media instructional strategies. The asynchronous approaches included posting recorded lectures and other content on the LMS, which the preservice teachers would download in ways that utilized less internet data. The use of multimedia, including social media, support online learning (Borup et al., 2012; Krutka et al., 2017; Lowenthal, 2010).

The second finding shows that only in a few instances was the teaching presence facilitated synchronously by teacher educators in the online classrooms. The teacher educators had to find alternative ways to engage the preservice teachers and maintain a teaching presence. Therefore, in most cases, the teaching presence was facilitated through a weekly uploading of content on the LMS and the WhatsApp social media platform, using PowerPoint presentations with voiceovers, voice notes, and emails containing clarification and explanation of concepts. The uploaded material consisted of content to be studied by the preservice teachers and the guidance, orientation, and instructions, all of which comprised the learning discourse. Szeto (2015) recognized the leadership role played by teaching presence in online classrooms. The three components of teaching presence which are the instructional organization, facilitating discourse, and direct instruction, according to DeNoyelles et al. (2014), had to be adjusted to align with the asynchronous strategies. The teacher educators conducted the instruction 
Maria, T., Transition to online learning by a teacher education program with limited 4IR affordances

organization by systematically posting materials using pre-recorded multimedia that the preservice teachers could download. The educators facilitated the discourse through the texts, recorded audio, and video presentations which mainly served as direct instruction tools.

The third finding showed that the social presence was influenced by the nature of the loT tools used and how the teaching presence directed it. The WhatsApp social media platform provided an opportunity for the teacher educators and the preservice teachers to form social groups for communication, discussions, and sharing of content. The WhatsApp platform was more accessible, cheap, and temporal, unlike the Blackboard LMS, which was more expensive for the preservice teachers regarding internet service costs. The WhatsApp groups formed an important tool to ensure that the preservice teachers felt that they were part of a social community where they could interact. Thompson et al. (2017) explain that social presence is facilitated when individuals feel they are part of a group. Groupwork was also facilitated because the preservice teachers could function as real people in the virtual environment because they could communicate and share ideas (DeNoyelles et al., 2014). The discussion forums on the LMS were also useful to enable interaction.

The fourth finding showed that although the preservice teachers mainly interacted individually with posted content, the cognitive presence was enhanced by collaboration activities enabled by the virtual groupwork and discussion forums. Whenever the social presence was enabled, the preservice teachers could co-construct meanings of what they were learning. After all, DeNoyelles et al. (2014) indicated that the three forms of presence are interrelated. The preservice teachers considered the recorded materials in the form of pre-recorded audio and videos as passive ways of learning. Passive ways of learning may require preservice teachers to employ increased self-regulated learning, which is a premise of success in online learning (Cho et al., 2017; Shea \& Bidjerano, 2012).

\section{Conclusion}

The participating preservice teachers and teacher educators at the university rural campus lived in communities with limited internet connectivity. The teacher education program transitioned to online learning through the use of a mix of the university LMS, emails, and a social media platform due to the limited internet access. Asynchronous strategies of building teaching, social, and cognitive presence in the online classrooms were favored and used more than synchronous strategies, which were not supported by the limited loT affordances. The study findings highlight the inequitable access to the teaching presence, social presence, and cognitive presence experiences of learners in rural communities due the limited loT infrastructure. This study has limitations, including that the findings rely on the data from one case and could have been enhanced had a multi-case study design been used. The study recommends further studies to explore how to improve learning experiences of preservice teachers in communities with limited loT affordances.

\section{Acknowledgements}

The NRF of South Africa supported this research study through the Thuthuka Funding Instrument. 
Maria, T., Transition to online learning by a teacher education program with limited 4IR affordances

\section{References}

Abbasy, M. B., \& Quesada, E. V. (2017). Predictable influence of loT (Internet of things) in the higher education. International Journal of Information and Education Technology, 7(12), 914-920. http://www.ijiet.org/vol7/995-T49.pdf

Aldowah, H., Ul Rehman, S., Ghazal, S., \& Umar, I. N. (2017). Internet of things in higher education: A study on future learning. J. Phys.: Conf. Ser., 892, 012017. https://doi.org/10.1088/1742-6596/892/1/012017

Allen, J., Rowan, L. \& Singh, P. (2020) Teaching and teacher education in the time of COVID19, Asia-Pacific Journal of Teacher Education, 48(3), 233-236. https://doi.org/10.1080/1359866X.2020.1752051

Anderson, T., Rourke, L., Garrison, D. R., \& Archer, W. (2001). Assessing teaching presence in a computer conference environment. Journal of Asynchronous Learning Networks, 5(2), 1-17. http://www.sloanconsortium.org/sites/default/files/v5n2 anderson 1.pdf

Arroio, A. (2020). The value of education in the context of Covid-19 pandemic. Problems of Education in the 21st Century, 78(3), 309-313. https://doi.org/10.33225/pec/20.78.309

Baran, E. \& AlZoubi, D. (2020). Human-Centered Design as a Frame for Transition to Remote Teaching during the COVID-19 Pandemic. Journal of Technology and Teacher Education, 28(2), 365-372. https://www.learntechlib.org/primary/p/216077/.

Bayani, M., Segura, A., Saenz, J., \& Mora, B. (2017). Internet of things simulation tools: Proposing educational components. SIMUL 2017: The Ninth International Conference on Advances in System Simulation, Greece, Athens.

Carrillo, C., \& Flores, M. A. (2020). COVID-19 and teacher education: A literature review of online teaching and learning practices. European Journal of Teacher Education, 43(4), 466-487. https://doi.org/10.1080/02619768.2020.1821184

Borup, J., West, R.E. \& Graham, C.R. (2012). Improving online social presence through asynchronous video. Internet and Higher Education, 15, 195- 203. https://doi.org/10.1016/j.iheduc.2011.11.001

Catalano, A. J., Torff, B., \& Anderson, K. S. (2021). Transitioning to online learning during the COVID-19 pandemic: Differences in access and participation among students in disadvantaged school districts. International Journal of Information and Learning Technology, 38(2), 258-270. https://doi.org/10.1108/IJILT-06-2020-0111

Chang, J. J., Lin, W. S., \& Chen, H. R. (2019a). A MOOC approach for training researchers in developing countries. Open Praxis, 9(1), 45-57. http://dx.doi.org/10.5944/openpraxis.9.1.476

Chang, J. J., Lin, W. S., \& Chen, H. R. (2019b). How attention level and cognitive style affect learning in a $\mathrm{MOOC}$ environment? Based on the perspective of brainwave analysis. Computers in Human Behavior, 100, 209-217. https://doi.org/10.1016/j.chb.2018.08.016

Cho, M. H., Kim, Y., \& Choi, D. (2017). The effect of self-regulated learning on college students' perceptions of community of inquiry and affective outcomes in online learning. The Internet and Higher Education, 34, 10-17. http://dx.doi.org/10.1016/j.iheduc.2017.04.001 
Maria, T., Transition to online learning by a teacher education program with limited 4IR affordances

Commonwealth of Learning. (2020). Guidelines on distance education during COVID-19. http://oasis.col.org/bitstream/handle/11599/3576/2020 COL Guidelines Distance E d COVID19.pdf?sequence $=4$

Creswell, J.W. (2014). Research Design: Qualitative, Quantitative, and the Mixed method: Sappro DeVries

Cutri, R. M., Mena, J., \& Whiting, E. F. (2020). Faculty readiness for online crisis teaching: Transitioning to online teaching during the COVID-19 pandemic. European Journal of Teacher Education, 43(4), 523-541. https://doi.org/10.1080/02619768.2020.1815702

DeNoyelles, A., Mannheimer Zydney, J., \& Chen, B. (2014). Strategies for creating a community of inquiry through online asynchronous discussions. Journal of Online Learning \& Teaching, 10(1), 153-166. http://jolt.merlot.org/vol10no1/denoyelles 0314.pdf

Garrison, D. R., Anderson, T., \& Archer, W. (2000). Critical inquiry in a text-based environment: Computer conferencing in higher education. The Internet and Higher Education, 2, 87-105. http://dx.doi.org/10.1016/S1096-7516(00)00016-6

Hajibayova, L. (2017). Students' viewpoint: What constitutes presence in an online classroom? Cataloging \& Classification Quarterly, 55(1), 12-25. https://doi.org/10.1080/01639374.2016.1241972

Hernandez, L., Jimenez, G., Baloco, C., Jimenez, A., \& Hernandez, H. (2018). Characterization of the use of the Internet of things in the institutions of higher education of the City of Barranquilla and its metropolitan area. In: C. Stephanidis (Ed.), HCl International 2018 - Posters' Extended Abstracts. HCL 2018. Communications in Computer and Information Science, 852 (pp. 17-24). Springer. https://doi.org/10.1007/978-3-319$\underline{92285-0 \quad 3}$

Isidro, E., \& Teichert, L. (2021). Towards Socially Just Literacy Teaching in Virtual Spaces. Journal of Curriculum Studies Research, 3(1), 21-41. https://doi.org/10.46303/jcsr.2021.6

Kalimullina, O., Tarman, B. \& Stepanova, I. (2021). Education in the Context of Digitalization and Culture: Evolution of the Teacher's Role, Pre-pandemic Overview. Journal of Ethnic and Cultural Studies, 8(1), 226-238. DOI: http://dx.doi.org/10.29333/ejecs/629

Kivunja, C., \& Kuyini, A. B. (2017). Understanding and applying research paradigms in educational contexts. International Journal of Higher Education, 6(5), 26-41. https://doi.org/10.5430/ijhe.v6n5p26

Kortuem, G., Bandara, A., Smith, N., Richards, M., \& Petre, M. (2013). Educating the Internetof-things generation. Computer, 46(2), 53-61. https://doi.org/10.1109/MC.2012.390

Krutka, D.G., Nowell, S. \& Mcmahon-Whitlock, A. (2017). Towards a Social Media Pedagogy: Successes and Shortcomings in Educative Uses of Twitter with Teacher Candidates. The Journal of Technology and Teacher Education, 25(2), 215240. https://www.learntechlib.org/primary/p/161880/

Lemay, D.J., Doleck, T. \& Bazelais, P. (2021). Transition to online teaching during the COVID-19 pandemic, Interactive Learning Environments. https://doi.org/10.1080/10494820.2021.1871633 
Maria, T., Transition to online learning by a teacher education program with limited 4IR affordances

Lowenthal, P.R. (2010). From pixel on a screen to real person in your students' lives:

Establishing social presence using digital storytelling. Internet and Higher Education, 13, 70-72. https://doi.org/10.1016/j.iheduc.2009.10.004

Makamure, C., \& Tsakeni, M. (2020). Covid-19 as an agent of change in teaching and learning STEM subjects. Journal of Baltic Science Education, 19(6A), 1078-1091. https://doi.org/10.33225/jbse/20.19.1078

Manly, C. A., Wells, R. S., \& Kommers, S. (2020). Who are rural students? How definitions of rurality affect research on college completion. Research in Higher Education, 61, 764-779. https://doi.org/10.1007/s11162-019-09556-w

McGinnis, D. (2018). What is the Fourth Industrial Revolution? https://www.salesforce.com/blog/2018/12/what-is-the-fourth-industrial-revolution4IR.html

Melville, N. P. \& Robert, L. (May 1, 2021). Towards Human-Centric Futures: Machine Capabilities \& Coordination as a Basis for a Reformulated 4IR. Available at SSRN: https://ssrn.com/abstract=3728052 or http://dx.doi.org/10.2139/ssrn.3728052

Mershad, K., \& Wakim, P. (2018). A learning management system enhanced with Internet of things applications. Journal of Education and Learning, 7(3), 23-40. https://doi.org/10.1109/COMAPP.2018.8460302

Mutton, T. (2020) Teacher education and Covid-19: responses andopportunities for new pedagogical initiatives, Journal of Education for Teaching, 46(4), 439-441. https://doi.org/10.1080/02607476.2020.1805189

Nelson, K. S., Nguyen, T. D., Brownstein, N. A., Garcia, D., Walker, H. C., Watson, J. T., \& Xin, A. (2021). Definitions, measures, and uses of rurality: A systematic review of the empirical and quantitative literature. Journal of Rural Studies, 82, 351-365. https://doi.org/10.1016/j.jrurstud.2021.01.035

Nowell, L. S., Norris, J. M., White, D. E., \& Moules, N. J. (2017). Thematic analysis: Striving to meet the trustworthiness criteria. International Journal of Qualitative Methods, 16(1). https://doi.org/10.1177\%2F1609406917733847

Panergayo, A. A. E., \& Almanza, M. R. G. (2020). Exploring the online learning self-efficacy of teacher education students at the Laguna State Polytechnic University: Basis for transition to flexible learning system. Universal Journal of Educational Research, 8(12), 6598-6608. https://www.hrpub.org/download/20201130/UJER24-19520427.pdf

Saadatmand, M., Uhlin, L., Hedberg, M., Åbjörnsson, L., \& Kvarnström, M. (2017). Examining learners' interaction in an open online course through the community of inquiry framework. European Journal of Open, Distance and e-Learning, 20(1), 61-79.

Schwab, K. (2016). The Fourth Industrial Revolution: What it means, how to respond? https://www.weforum.org/agenda/2016/01/the-fourth-industrial-revolution-what-itmeans-and-how-to-respond/

Scott, K. S., Sorokti, K. H., \& Merrell, J. D. (2016). Learning "beyond the classroom" within an enterprise social network system. Internet and Higher Education, 29, 75-90. https://doi.org/10.1016/j.iheduc.2015.12.005

Shea, P., \& Bidjerano, T. (2012). Learning presence as a moderator in the community of inquiry model. Computers \& Education, 59(2), 316-326.

http://dx.doi.org/10.1016/j.compedu.2012.01.011 
Maria, T., Transition to online learning by a teacher education program with limited 4IR affordances

Subedi, D., \& Subedi, R. (2020). Practicing Self Learning of ICT for Resilience Amidst the COVID-19 Outbreak: Experiences from Kathmandu Valley. Research in Educational Policy and Management, 2(2), 78-96. https://doi.org/10.46303/repam.2020.5

Szeto, E. (2015). Community of inquiry as an instructional approach: What effects of teaching, social and cognitive presences are there in blended synchronous learning and teaching? Computers \& Education, 81, 191-201. http://dx.doi.org/10.1016/j.compedu.2014.10.015

Swarts, G. P (2020). Re/coding global citizenship: How information and communication technologies have altered humanity and created new questions for global citizenship education. Research in Social Sciences and Technology, 5(1), 70-85.

Thompson, P., Vogler, J. S., \& Xiu, Y. (2017). Strategic tooling: Technology for constructing a community of inquiry. Journal of Educators Online, 14(2), n2.

Williams, T. K., McIntosh, R. W., \& Russell, W. B. (2021). Equity in distance education during COVID-19. Research in Social Sciences and Technology, 6(1), 1-24.

https://doi.org/10.46303/ressat.2021.1 